\title{
Intrafamilial spread of hepatitis B: \\ Passage through several generations
}

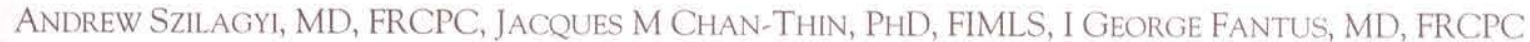

\begin{abstract}
A SZILAGYI, J CHAN-THIM, I FANTUS. Intrafamilial spread of hepatitis B: Passage through several generations. Can J Gastroenterol 1993;7(1):23-27. Uncontrolled spread of hepatitis B virus (HBV) is described in an immigrant Italian family. As many as four generations of offspring appear to have been infected, the source likely originating from a great grandfather. Overt liver disease in four of six members in the second generation as well as a history of hepatitis implicates the virus in the two generations which could not be tested. Five of seven asymptomatic sisters in generation III were found to be carriers, and were both hepatitis B surface antigen $(\mathrm{HBs} \mathrm{Ag})$-positive and antihepatitis $\mathrm{Be}$ antigen antibody-positive. One sister lost $\mathrm{HBsAg}$ status shortly after discovery of her carrier status. The overt carrier rate in generation IV was reduced, suggesting later childhood acquisition of HBV infection. This family strongly emphasized the need for investigating patients with a positive family history of liver disease and screening family members of newly discovered $\mathrm{HBsAg}$ carriers to allow appropriate measures to be taken to limit the spread of HBV.
\end{abstract}

Key Words: Hepatitis familial infection

\section{Transmission de l'hépatite $\mathbf{B}$ entre les générations d'une même} famille

RÉSUMÉ: La transmission non maîtrisée du virus de l'hépatite B est décrite au sein d'une famille d'immigrants italiens. Jusqu'à quatre générations semblent avoir été infectées, la source originant probablement d'un arrière-grand-père. Une maladie hépatique évidente chez quatre des six membres de la deuxième

Division of Gastroenterology, Department of Medicine and Department of Microbiology, Sir Mortimer B Davis - Jewish General Hospital, Division of Endocronology, Royal Victoria Hospital and McGill University, Montreal, Quebec

Correspondence and reprints: Dr A Szilagyi, 100-6000 Côte-des-Neiges, Montréal, Québec H3S 128. Telephone (514) 739-7370

Received for publication December 5, 1991. Accepted July 6, 1992
ONSEQUENCES OF CHRONIC HEP. atitis $B$ virus (HBV) infection pose an important economic burden, and cause significant morbidity and mortality. In areas of high or midprevalence of $\mathrm{HBV}$, most infections are acquired in the neonatal or early childhood period (1-3). In low prevalence areas, specific high risk lifestyles predispose to infection $(1,2)$. However, a large proportion of cases are related to inapparent sources (4). In such cases the contribution of occult intrafamilial spread of HBV may be overlooked and thus, an opportunity to limit further HBV spread may be missed. Intrafamilial spread both of HBV (5-7) and hepatocellular carcinoma - strongly associated with HBV $(8,9)$ - have been described.

The mechanism of intrafamilial spread has been linked both to vertical transmission (10) and horizontal spread (6) among members of the same or other families. At least one earlier study from North America found little likelihood of horizontal or vertical spread (11). To emphasize the usefulness of current efforts to minimize HBV spread and to shed a historical perspective on 
génération, de même que des antécédents d'hépatite, identifient le virus dans les deux générations qui n'ont pas pu être soumises à l'épreuve. Cinq des sept soeurs asymptomatiques de la génération III se sont révélées porteuses et positives à l'égard de l'antigène de surface de l'hépatite $B(\mathrm{Ags} H \mathrm{~B})$ et à l'égard d'un anticorps anti-antigène de l'hépatite $B$ e. L'une des soeurs a perdu son statut $\mathrm{AgsHB}$ peu de temps après avoir découvert son statut de porteuse. Le taux de porteurs déclarés dans la génération IV a été moindre, donnant à supposer une acquisition plus tardive durant l'enfance de l'infection au HBV. Cette famille souligne nettement la nécessité de pratiquer un dépistage chez les patients qui présentent des antécédents familiaux positifs d'hépatite et le dépistage des membres des familles de porteurs $\mathrm{AgsHB}$ nouvellement diagnostiqués afin de promouvoir les mesures appropriées pour limiter la propagation du HBV. the hazards of unchecked HBV infection, the authors report a family who immigrated from southern Italy with as many as four generations possibly with HBV likely via both horizontal and vertical spread. Such transmission of $\mathrm{HBV}$, spanning several generations, has rarely been reported $(12,13)$.

\section{SUBJECTS AND METHODS}

The index case was referred for a positive strong history of liver disease. This included hepatocellular carcinoma in her father, possible liver disease in a paternal aunt, and blood test abevaluation of a thyroid nodule and gave normalities of liver function in a sister. A screen for hepatitis B surface antigen ( $\mathrm{HBs} A G)$ was positive and the patient was referred for further evaluation. Subsequently, seven sisters, four of their spouses in generation III and nine of their children in generation IV were tested. One additional neonate in generation IV was subsequently vaccinated at birth.

$\mathrm{HBs} \mathrm{Ag}$, anti-HBsAg antibody, hepatitis Be antigen (HBeAg) anti-HBeAg antibody, immunoglobin ( $\mathrm{Ig}$ ) $\mathrm{G}$ antihepatitis $\mathrm{Bc}$ antigen ( $\mathrm{HBc} \mathrm{Ag}$ ) antibody were measured by standard assay (Enzyme Immunoassay, Boehring diagnos-

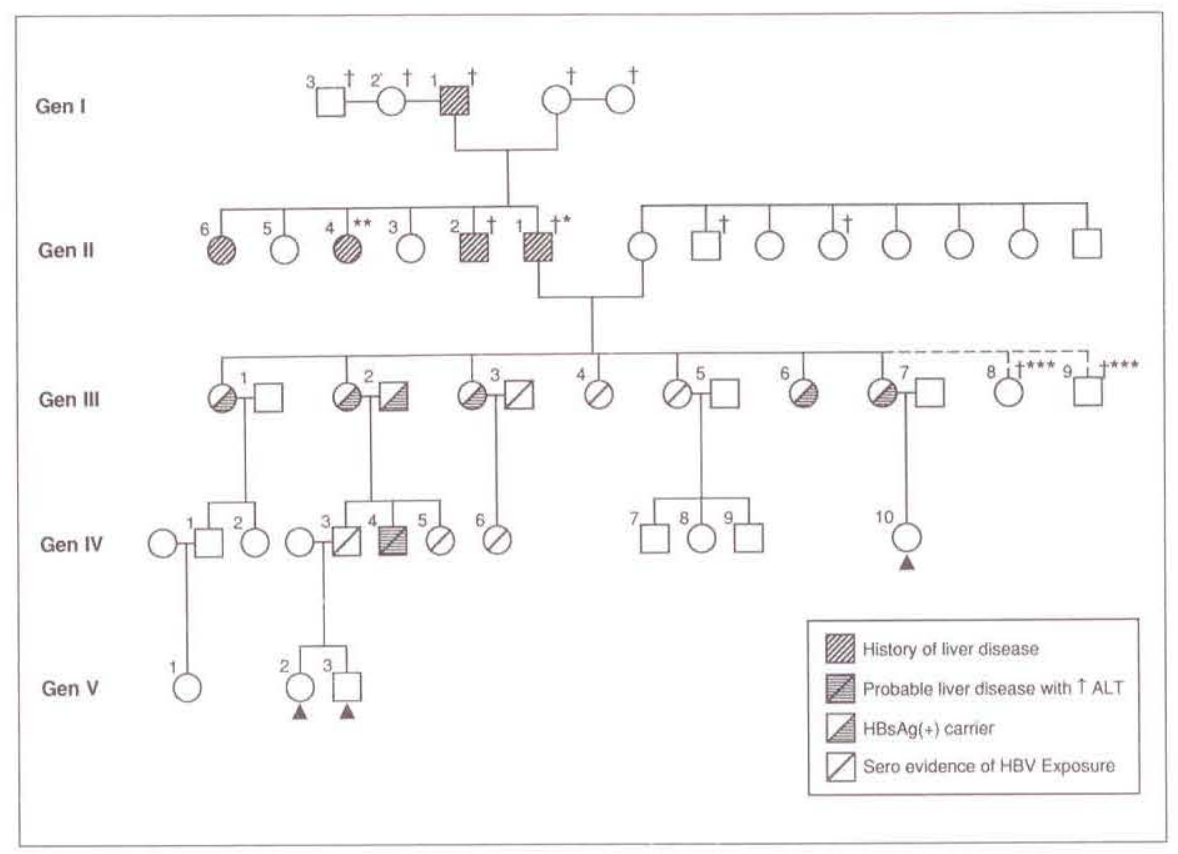

Figure 1) Intrafamilial spread of hepatitis B is depicted through four consecutive generations. Hepatitis B virus (HBV) serology was measured only in generations III and IV. The presence of frequent liver disease and a historical relationship to HBV in genertion II implicates the virus in the pathogenesis of the liver disease in generations I and II. Probable hepatocellular carcinoma; **History of positive HBV serology; ${ }^{* * * * N e o n a t a l ~ d e a t h ; ~}{ }^{\dagger}$ Died tics and Microparticle Enzyme Immunoassay, Abbott). All positive $\mathrm{HBs} \mathrm{Ag}$ were confirmed by reverse passive hemagglutination (Abbott Diagnostics, Illinois). Anti-HBcAg antibody were measured by Enzyme Immunoassay (Ortho Diagnostics). Wilson's disease, hemochromatosis and $\alpha 1$ antitrypsin deficiency were ruled out by standard methods.

\section{RESULTS}

Affected and probably affected members are shown in Figure 1. Historically, the great grandfather (generation I [Gen I]) migrated from Valsini in southern Italy to Turin in Maternal province. He was reported to have died in his early 50 s with ascites and jaundice. In Gen II, four of six siblings were reported to have had liver disease. The grandfather (Gen $\mathrm{Il}_{1}$ ) immigrated to Montreal and was reported to have died in his 50 s with ascites and probable liver cancer. The brother (Gen $\left.\mathrm{I}_{2}\right)$ apparently had cirrhosis, but was thought to drink alcohol excessively. Two other sisters in Italy have known liver disease and at least one recalled being told hepatitis B was the cause. Unfortunately, this branch of the family declined to be tested. There was no history of liver disease on the great grandmother or grandmother's side.

Gen III, seven females, were born in Italy and immigrated in the early 1960 s to Montreal with their parents. Their mean age at present is 40.7 years. Two additional siblings died as neonates. None of the sisters is symptomatic, and only one has mildly abnormal liver biochemistries (Gen $\mathrm{III}_{6}$ ). Their $\mathrm{ab}$. dominal ultrasound examinations were normal. Because of no direct serological evidence of HBV infection in Gen 1 and II, serum ceruloplasmin, serum iron studies and $\alpha \mathrm{l}$ antitrypsin were measured in six of seven sisters; these studies were uniformly negative. In addition, serology for anti-HBc was negative in five sisters of Gen III and two of their spouses.

The serological findings in the seven sisters, four of their spouses and nine children are listed in Table 1 . Tests were repeated at least three times during a 24-month observation period. 
All seven sisters were found to have evidence of exposure to HBV. Five were initially $\mathrm{HBs} \mathrm{Ag}$-positive and anti$\mathrm{HBeAg}$-positive. Within eight months of the initial tests, $\mathrm{III}_{3}$ converted from $\mathrm{HBs} \mathrm{Ag}$-positive to anti-HBsAg antibody-positive and lost $\mathrm{HBsAg}$. This event was verified by the finding of borderline negative $\mathrm{HBs} \mathrm{Ag}$ on repeat testing. Two other sisters had only antibodies; III5 had anti-HBsAg only and $\mathrm{IIl}_{4}$ had only positive $\mathrm{IgG}$ anti-HBcAg antibody found on all three tests. One of four spouses was $\mathrm{HBs} \mathrm{Ag}$-positive and anti-HBeAg-positive while one was positive only for anti-HBsAg.

In Gen IV (mean age 15.7 years) three children from $\mathrm{III}_{5}(\mathrm{IV} 7,8,9)$ were negative for $\mathrm{HBV}$-related serology. Of the remaining six, $\mathrm{IV}_{4}$ was positive for both HBsAg and HBeAg. He also had mild asparate aminotransferase and alanine aminotransferase elevations. This subject has no known either risk factors for HBV infection. The brother and sister of $\mathrm{IV}_{4}\left(\mathrm{IV}_{3}\right.$ and $I V_{5}$, respectively) both have anti-HBsAg and anti- $\mathrm{HBeAg}$ but are otherwise asymptomatic. One cousin, $I V_{6}$, was also anti$\mathrm{HBs} A g$-positive. In addition, the neonate $\left(\mathrm{Gen} I \mathrm{~V}_{10}\right)$ was vaccinated against $\mathrm{HBs} A$, and $G e n V_{2}$ and $V_{3}$ were vaccinated because of close contact with Gen $\mathrm{III}_{2}$.

\section{DISCUSSION}

Familial clustering of $\mathrm{HBV}$ infection or hepatoma has been previously described $(5-9,12,13)$. What is interesting about this family is that probably four successive generations were affected by HBV. Also of interest is the observation that the likely source of infection in Gen I and II could be traced to the father's side. Finally, it is noteworthy that the successive unchecked passage of HBV led to an apparent natural reduction in the number of HBs Ag carrier children by the fourth generation.

Infection with HBV can occur by several routes. Blood transfusion (now rare) (14), shared needles and sexual contact are well described $(15-17)$ but do not represent the majority of traced infections in North America (4). With the exception of stool, HBV has been

TABLE 1

Hepatitis B serology in generations III and IV and their spouses

\begin{tabular}{|c|c|c|c|c|c|c|}
\hline Gen/spouse & $\begin{array}{c}\text { Age } \\
\text { (years) }\end{array}$ & HBsAg & anti-HBsAg & $\mathrm{HBeAg}$ & anti-HBeAg & anti-IgGHBCAg \\
\hline Gen III & 49 & + & - & - & + & + \\
\hline Spouse & 56 & ND & ND & ND & ND & ND \\
\hline Gen IV & 27 & - & - & - & - & - \\
\hline GenIV/2 & 23 & - & - & - & - & - \\
\hline Genlll 2 & 47 & + & - & - & + & + \\
\hline Spouse & 51 & + & - & - & + & ND \\
\hline Gen IV 3 & 26 & - & + & - & + & ND \\
\hline Gen IV 4 & 24 & + & - & + & - & + \\
\hline Gen IV 5 & 28 & - & + & - & + & ND \\
\hline Gen $\mathrm{II}_{3}{ }^{*}$ & 43 & + & - & - & + & + \\
\hline Spouse & 49 & - & + & - & + & + \\
\hline Gen IVo & 25 & - & + & - & - & + \\
\hline Gen $\|_{4}^{\dagger}$ & 40 & - & - & - & - & + \\
\hline Gen $\|_{5}$ & 38 & - & + & - & - & + \\
\hline Spouse & 36 & - & - & - & - & - \\
\hline Gen IV7 & 8 & - & - & - & - & - \\
\hline Gen IV8 & 6 & - & - & - & - & - \\
\hline Gen IV9 & 4 & - & - & - & - & - \\
\hline Gen IIIb & 35 & + & - & - & + & + \\
\hline Gen III7 & 32 & + & - & - & + & + \\
\hline Spouse & 33 & - & - & - & - & - \\
\hline GenIV $_{10}$ & 0.5 & \multicolumn{2}{|c|}{ Vaccinated } & & & \\
\hline
\end{tabular}

"Subject converted to antihepatitis B surface antigen (HBSAg) within eight months of first test; ' Retest done 12 months later revealed same pattern: Gen Generation; HBeAg Hepatitis Be surface antigen: IgGHBCAg Immunoglobulin G hepatitis Bc antigen; ND Not done

isolated from all bodily secretions (18). However, because up to $70 \%$ of infections with HBV are subclinical (4), tracing sources may be quite difficult. While 5 to $10 \%$ of infected adults become carriers, as many as $90 \%$ of infected neonates born to $\mathrm{HBeAg}$ positive mothers will be carriers (19). Older children have an intermediate rate of carrier status. The age dependency on outcome of HBsAg carrier rate has a major impact on geographical epidemiology of HBV carriage. For example, in the Orient where a large exposure to $\mathrm{HBV}$ occurs through vertical transmission, the $\mathrm{HBsAg}$ carrier rate is the highest (20). In the Mediterranean, infectivity is believed to occur in older children largely through horizontal spread and their carriage rates are much lower (21). In North America, HBV exposure occurs mainly in minority immigrants or among high risk adult populations leading to a much smaller HBV carriage rate (21). Immigrants from endemic areas retain their carrier rates (22).

Early reports on intrafamilial spread of HBV or clustering of hepatoma focused on possible genetic predisposition to either carriage or carcinogenesis $(23,24)$. Figure 1 certainly could be interpreted in the light of a dominant mode of inheritance of HBV with incomplete penetrance in Gen IV. However, early reports did not take into consideration the biological behaviour of $\mathrm{HBV}$ and a genetic linkage was not verified (25).

Intrafamilial spread traced to the paternal side is reported much less often than maternal sources (26). The mechanism of spread under these circumstances relates either to subclinical infection to the mother (consequently in whom high replicative $\mathrm{HBe} \mathrm{Ag}$ - positivity occurs) or more likely to horizontal transmission through close familial contact (27).

The apparent passage of HBV through multiple generations has been reported only occasionally. Three successive generations affected by hepatoma were reported by Lok et al (12) supporting the notion of multigeneration passage of HBV (12). Although 
historical inference imply that Gen I and II were infected, the elimination of other genetic liver disease and the uniform positive HBV serology in sisters of Gen III coupled with the high penetrance of liver disease in Gen II strongly implicate HBV as being pathogenic in both Gen I and II. Such a generational spread of HBV was also documented in a study of another Italian American family in which two-thirds of five generations had evidence of positive HBV serology (13).

The authors noted that the carrier rate of $\mathrm{HBs} \mathrm{Ag}$ decreased by the fourth generation (five of seven, $71 \%$ Gen III versus one of six, $17 \%$ Gen IV). There is no clear explanation for this apparent reduction. Large population-based studies from both Italy and Japan also noted a carrier rate reduction in

ACKNOWLEDGEMENT: The authors thank Ms Lina Ricci for assistance in the preparation of the manuscript.

\section{REFERENCES}

1. Anderson ME, Murray-Lyon IM. Natural history of HBsAg carrier. Gut 1985;26:848-60.

2. Francis DP, Favero MS, Maynard JE. Transmission of hepatitis B virus. Semin Liver Dis 1981;1:27-32.

3. Lok ASF, Lai CH, Wu PC, Wong VCW, Yeoh EK, Lin HJ. Hepatitis B virus infection in chinese families in Hong Kong. Am J Epidemiol 1987;126:492-9.

4. Hoofnagle JH. Type B hepatitis, virology, serology and clinical course. Semin Liver Dis 1981;1:7-14.

5. Koff RS, Slavin MM, Connelly LJD, Rosen DR. Contagiousness of acute hepatitis B secondary attack rates in household contacts. Gastroenterology 1977;72:297-300.

6. Lin HJ, Lai CL, Lau JYN, Chung HT, Lauder IJ, Fong MW. Evidence for intrafamilial transmission of hepatitis B virus from sequence analysis of mutant HBV DNAs in two chinese families. Lancet 1990;336:208-12.

7. Hess C, Bom M, Dormeyer H, Zeller B, Arnold W, Knolle J. Hepatitis B virus markers among family contacts of asymptomatic HBsAg carriers. Scand J Gastroenterology 1979;14:373-8.

8. Denison EK, Peters RL, Reynolds TB. Familial hepatoma with hepatitis associated antigen. Ann Intern Med $1971 ; 74: 391-4$ children of HBsAg-positive mothers $(28,29)$. Plausible explanations include an improvement in socioeconomic conditions and decreased family size (which limits sibling spread). Nevertheless, HBV infectivity remained high in Gen IV since four of six children had HBV markers. Therefore, one wonders why three of four children cleared $\mathrm{HBsAg}$ in Gen IV and not in Gen III (since the rate of $\mathrm{HBsAg}$ clearance in carriers is no more than 1 to $2 \%$ per year [30]). It is possible that in Gen IV the children acquired subclinical hepatitis horizontally, in which case the clearance is higher and carrier rate is lower. The observation that passage of $\mathrm{HBV}$ infection is much less efficient in anti-HBeAg-positive mothers supports this notion $(4,19)$. Although the mothers in Gen III began delivering in their early and late 20s, we are not cer-

9. Ohbayashi A, Okochi K, Mayumi M. Familial clustering of asymptomatic carriers of Australia antigen and patients with chronic liver disease or primary liver cancer. Gastroenterology 1972;62:618-25.

10. Stevens CE, Beasley RP, Tsui J, Lee WC. Vertical transmission of hepatitis $B$ antigen in Taiwan. N Engl J Med 1975;292:771-4.

11. Szmuness W, Prince AM, Hirsch RL, Brotman B. Familial clustering of hepatitis B infection. N Engl J Med 1973;289:1162-6.

12. Lok ASF, Lai CL. Factors determining the development of hepatocellular carcinoma in hepatitis B surface antigen carriers. A comparison between families with clusters and solitary cases. Cancer 1988;61:1287-91.

13. Sampliner RE, Loevinger BL, Tabor E, Gerety RJ. Intrafamilial cluster of hepatitis B virus infection: Study of a large family in the United States. Am J Epidemiol 1981;113:50-4.

14. Alter HJ, Tabor E, Meryman HT, et al. Transmission of hepatitis $B$ virus infection by transfusion of frozendeglycerolized red blood cells. N Engl ] Med 1978;298:638-42.

15. Alter MJ, Hadler SC, Margolis HS, et al. The changing epidemiology of hepatitis B in the United States. Need for alternative vaccination strategies. JAMA 1990;263:1218-22.

16. Reiner NE, Judson FN, Bond WW, Francis DP, Petersen NJ. Asymptomatic rectal mucosal lesions and hepatitis B surface antigen to sites of sexual contact in homosexual men tain that mothers in this generation were anti-HBeAg-positive at delivery. These results also differ from Sampliner et al (13) whose work indicated that 13 of 18 children born to $\mathrm{HBs} A g$ mothers became carriers. Further study of this discrepancy is required.

\section{CONCLUSIONS}

In summary, the present authors report a family in which at least four generations may have been infected with HBV. The combination of serological findings suggest that both vertical and horizontal spread were responsible for dissemination of the infection. This family study re-emphasizes the need for close historical and medical scrutiny of newly discovered patients with HBV. Appropriate medical intervention will then limit further spread of this potentially lethal infection.

with persistent hepatitis $B$ virus infection: Evidence for defacto parenteral transmission. Ann Intern Med 1984;96:170-3.

17. Szmuness W, Much I, Prince AM, et al. On the role of sexual behavior in the spread of hepatitis B infection. Ann Intern Med 1975;83:489-95.

18. Villarejos VM, Kristen A, Visona MS, Gutierrez A, Rodriquez A. Role of saliva, urine and feces in the transmission of type B hepatitis. N Engl J Med 1974;291:1375-8.

19. Okada K, Kamiyama I, Inomata M, Imai M, Miyakawa Y, Mayumi M. Antigen and anti-e in the serum of symptomatic carrier mothers as indicators of positive and negative transmission of hepatitis B virus to their infants. N Eng J Med 1976;294:746-9.

20. Stevens CE, Beasley RP, Tsui J, Lee WC. Vertical transmission of hepatitis $B$ antigen in Taiwan. N Engl J Med 1975;292:771-4.

21. Margolis HS, Alter MJ, Hadler SC. Hepatitis B: Evolving epidemiology and implications for control. Semin Liver Dis 1991;II:84-92.

22. Franks AL, Berg CJ, Kone MA, et al. Hepatitis $B$ virus infection among children born in the United States to southeast Asian refugees. N Engl J Med 1989;321:1301-5.

23. Carbonara $\mathrm{AO}$, Trinchieli $\mathrm{G}$, Bedarida G, Filippi G. A caucasian population with a high frequency of Au carriers genetic analysis of the condition. Vox Sang 1970;19:288-94. 
24. Hillis WD, Hillis A, Bias WB, Walker WG. Associations of hepatitis B surface antigenemia with HLA locus B specificities. N Eng J Med 1977;296:1310-4.

25. Kew MC, Gear AJ, Baumgarten I, Dusheiko GM, Maier G. Histo compatibility antigens in patients with hepatocellular carcinoma and their relationship to chronic hepatitis B virus infection in these patients. Gastroenterology 1979;77:537-9.

26. Washiwagi S, Hayashi J, Ikematsu $\mathrm{H}$, et al. Transmission of hepatitis B virus among siblings. Am J Epidemiol 1984;120:617-25.

27. Toukan AU, Sharaiha ZK, AbuelRub OA, et al. The epidemiology of hepatitis $B$ virus among family members in the middle East. Am J Epidemiol 1990;132:220-32.

28. Stroffolini T, Mattia DD, Compagnone A, Arcamone GP, Altomare M, Schettini F. Age-specific prevalence of hepatitis $B$ virus infection among children in an endemic area in Southern Italy.
Pediatr Infect Dis 1990;9:407-10.

29. Kashiwagi S, Hayashi J, Nomura H, Kajiyama W, Ikematsu H, Noguchi A. Changing pattern of intrafamilial transmission of hepatitis B virus in Okinawa Japan. Am J Epidemiol 1988;127:783-7.

30. Sampliner RE, Hamilton FA, Iseri OA, Tabor E, Boitnott J. The liver histology and frequency of clearance of the hepatitis B surface antigen ( $\mathrm{HBs} \mathrm{Ag})$ in chronic carriers. Am J Med Sci 1979;177:17-22 


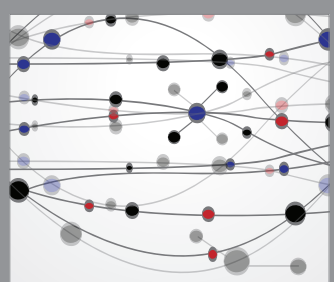

The Scientific World Journal
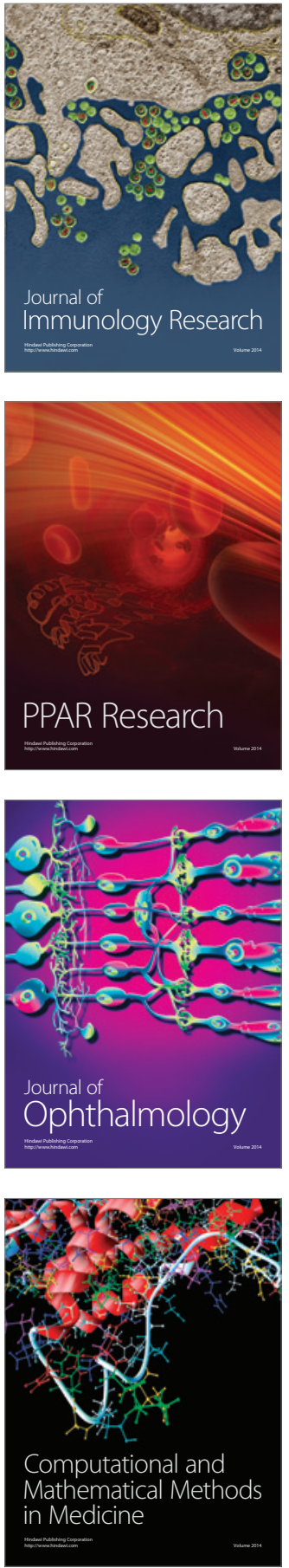

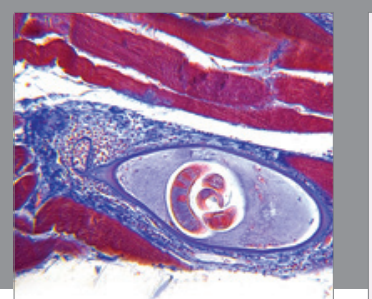

Gastroenterology Research and Practice

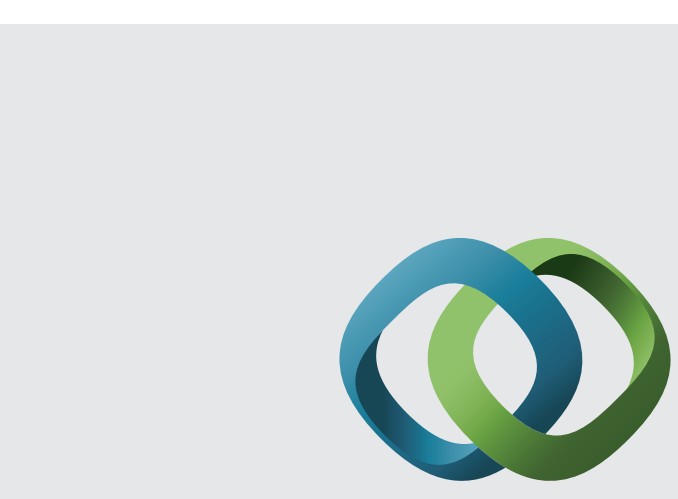

\section{Hindawi}

Submit your manuscripts at

http://www.hindawi.com
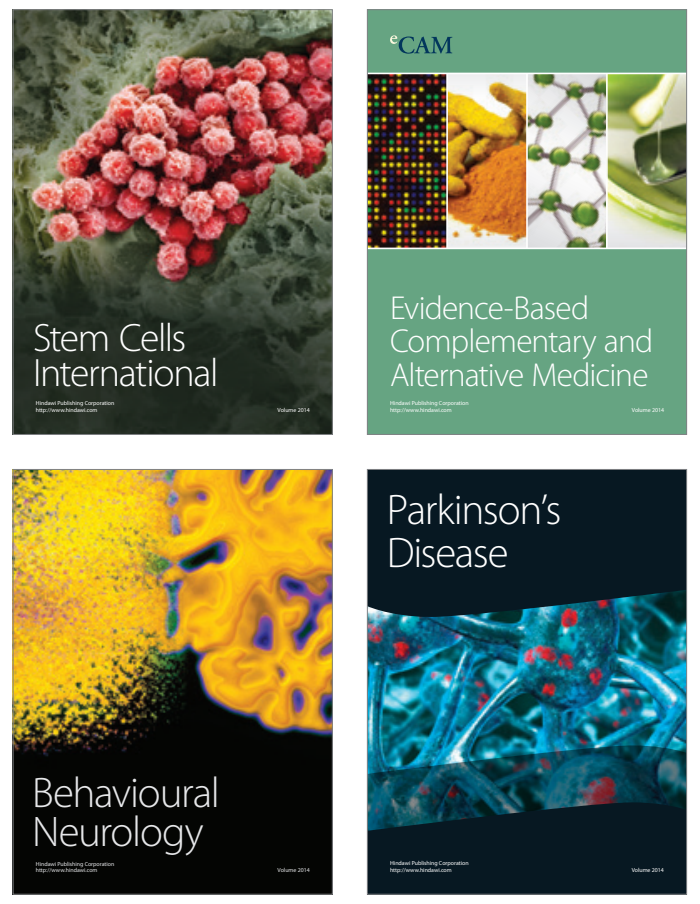
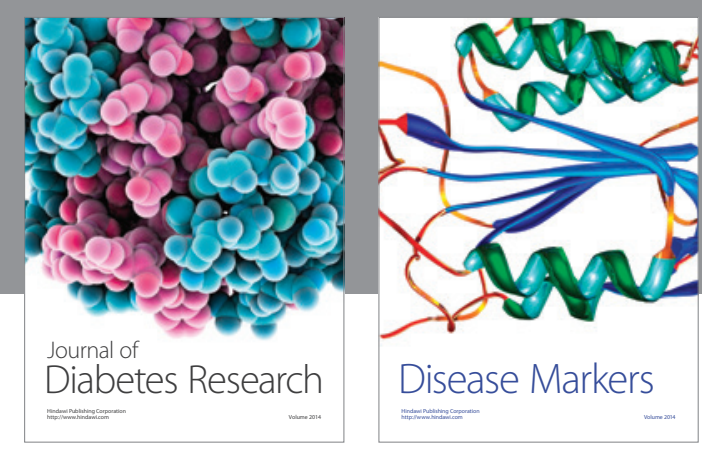

Disease Markers
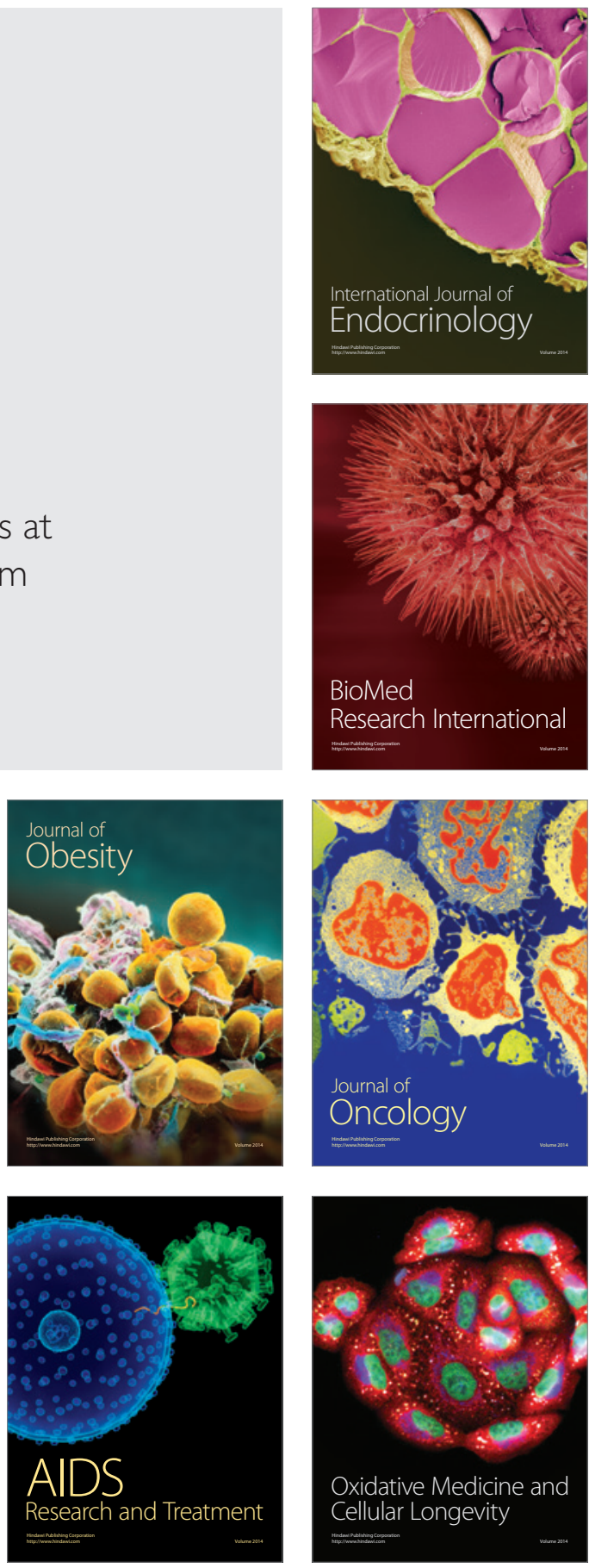